UDK 502.12

\title{
ЗДЕНАЦ НАРОДНЕ МУДРОСТИ И ЕКОЛОШКА СВЕСТ
}

\section{Резиме}

Данас је јако модерно и популарно говорити о екологији. Баук екологизма (да се послужимо Марксовом синтагмом, како је давно он говорио за комунизам) кружи светом. Међутим, у том говору у тим настојањима и бројним институтима и организацијама које се баве екологијом уочавамо јасан парадокс. Никад више говора о екологији, никад више еколошких покрета, никад више трошење новаца за решавање еколошких проблема, а чини се никад човечанство није било ближе апокалипси, највише управо из еколошких разлога. Новокомпоновани еколози, чија су уста пуна приче о еколошкој свести, али без практичног утемељења, ничу као печурке после кише. Ретки су они који себе називају еколозима, а који су схватили, како праву суштину еколошког проблема, а још мање они који виде прави излаз из мрака еколошке кризе у коју је човечанство запало. Шта је кључни ралог томе? Где леже уроци тог парадокаса. Овај рад управо има намеру да понуди један другачији поглед на узроке еколошке кризе и понуди другачије решење еколошког проблема.

Кључе речи: народна мудрост, еколошка криза, еколошка свест, екологија духа.

Зар Земља није најдражи дом за нас, юене становнике?

Зар није вредна наме љубави?

Зар не заслужује да јој посветимо сву нашу инвентивност, храброст и великодушност да бисмо је спасили од пропадања и уништења и на тај начин осигурали и њен и свој опстанак?

B. Vord, R. Dibo, Земља планета наша једина

\section{УВОД - ЧОВЕК НАСУПРОТ ПРИРОДИ = ЕКОЛОШКА КРИЗА}

Данас је јако модерно и популарно говорити о екологији. Баук екологизма (да се послужимо Марксовом синтагмом, како је давно он говорио за комунизам) кружи светом. Међутим, у том говору у тим настојањима и бројним институтима и организацијама које се баве екологијом уочавамо јасан парадокс. Никад више говора о екологији, никад више еколошких покрета, никад више трошење новаца за решавање еколошких проблема, а чини се никад човечанство није било

${ }^{1}$ Markomarcelo7@yahoo.com 
ближе апокалипси, највише управо из еколошких разлога. Човечан-

ство је данас конфротирало са мноштвом егзистенцијалних криза, међу којима еколошка криза заузима посебно место. Нигде се тако јасно не показују цветови наше људске болести, како би рекао Бодлер, као у еколошкој кризи којој смо ми данас сведоци. Свет којим смо окружени и кога смо саставни део, јесте јако крхка творевина коју смо својим непромишљеним деловањем у великој мери урушили. Новокомпоновани еколози, чија су уста пуна приче о еколошкој свести, али без практичног утемељења, ничу као печурке после кише. Међутим, ретки су они који себе називају еколозима, а који су схватили, како праву суштину еколошког проблема, а још мање они који виде прави излаз из мрака еколошке кризе у коју је човечанство запало. Основна грешка налази у томе што се не види прави узрок еколошке кризе а онда се и решења траже на погрешном месту.

Обично научници сматрају да техничка средства, као изум науке, једино могу утицати на поправљање еколошких проблема. Бек је у свом сјајном делу Ризично друштво јасно упозорио на опасност и врсте ризика са којима се суочава човечанство при чему посебно указује на науку која је главни узрочник тих ризика: “Динамика ризичног друштва не почива на претпоставци према којој данас и у будућности морамо да живимо у свету непостојећих опасности, већ да живимо у свету који о својој будућности мора да одлучује у условима произведене, самофабриковане несигурности. То имплицира да свет више не може да контролише опасности које производи модерна, тачније да је веровање да модерно друштво наводно може да контролише опасности које производи нестало не због пропуста и пораза модерне, него због њених победа“ (Бек, 2011: 23). То доводи, како примећује Бек да се све више ствара јаз између Бога и ризика.

„Када је ризик ступио на сцену, Бог је морао да се одрекне свог места господара света, са свим субверзивним консеквенцијама које то подразумевају. У одсуству Бога ризик достиже своју судбоносну и застрашујућу, готово недокучиву вишесмисленост. Свет није онакав какав је, него његово постојање и његова будућност зависе од одлука, одлука које одмеравају позитивне и негативне стране, које повезују прогрес с деградацијом и, као и све људско - заблуда, незнање, охолост, обећање контроле у себи нове заметак свога краја“. (Бек, 2011: 18-19)

Када је наука ступила на сцену и потиснула Бога, људи су наивно поверовали да ће технички развитак који је постављен фундаментом етике, створити земаљски рај, као замену за божански, из којег је због греха који је учинио протеран. Али десио се, како то обично и бива, преокрет, технички напредак измакао је контроли човека и делује као самостална, независна сила пред којом је човек исто толико немоћан колико је то био и пред тајанственим и непознатим силама природе. Свет људских дела извојевао је победу над светом човека. Техничко је победило хумано. Област вештачког гута природно, брише разлику 
имеђу природног и вештачког, ствара нову природу која представља највећи изазов људском постојању. За разлику од егзистенцијалних криза прошлости, кризе данашњице не потичу од природних непогода које су просторно ограничене, већ од глобалног несклада у идејноматеријалном смислу читаве индустријске цивилизације. Стога нам се чини да је Бек потуно у праву када предочава да еколошка проблематика није више проблематика која се тиче окружења, већ је у својој генези и својим последицама - потпуно друштвена, јер се тиче људи, њихове историје, животних услова, економске, политичке и културне датости... (Бек, 2011: 118). Овакав приступ намеће потребу развоја другачијег погледа како на природу али и самог човека.

На механицистичком обрасцу утемељено је модерно друштво и тиме је убрзана даља деградација света, живота и рада. Андре Горц открива спрегу између еколошке кризе и кризе савременог друштва. Критикујући профитерску логику, он тврди да су оба друштвена сценарија (западни и источни), прихватајући идеју раста, себе осудила на гомилање еколошких проблема. Горц јасно поручује: „Екологистички захтев је заснован на фундаметалним претпоставкама. Због тога он није подложан ценкању, погађању. Социјализам не вреди више од капитализма ако се служи истим оруђем. Потпуна владавина човека над природом неизбежно повлачи то да техника којом се та владавина врши доминира над човеком. У одсуству неког другог избора, још увек више вреди нуклеарни капитализам од нуклеарног социјализма, jep ће први мање оптеретити будућност" (Горц, 1982: 50). Постиндустријска друштва суочавају се са глобалним еколошким проблемима, чији је извор у механицистичком погледу на свет, на заблуди о победи човека над природом, те се може рећи, да друштвени развој који је почивао на схватању да је човек господар природе, а природа ,дивља сила коју треба укротити, оковати, натерати је да служи човеку и његовом победоносном ходу“ - како пише Бодријар, уз поистовећивање друштвеног раста и развоја, води у катастрофу. „Рушећи шуме и потапајући древна насеља, човек је постајао див. А од дива се не може очекивати да служи природи, да ослушкује њен унутрашњи ритам, да са њом усклађује своје тежње и жеље, као што се не може очекивати да једна идеологија, окренута против људске природе, природе економије и, уопште против природе ствари, има обзира према шумама, рекама и језерима“" (Бодријар, 1991: 143).

Од нашег односа према животној средини зависи живот нових генерација, то већ сада постаје јасно након више деценија индустријског развоја и технолошког прогреса, кратковидог напретка, који полако сече грану на којој седи, заслепљен сјајем спољних ствари. По инерцији иновација, узбудљивих открића у законима стварности, срљамо у амбис, што ће се десити уколико се не успоставе и не превладају јасни критеријуми смисла живота и организације друштва. Нажалост, ми се данас налазимо у неколико парадоксалних ситуација. Савремено и нуклеарно наоружање има могућност да уништи живот на земљи. Такође, технолошки и индустријски развој прети да уништи природу. Неконтролисани развој науке и технологије се надвија као 
Дамоклов мач над судбином цивилизације. Само од нашег морала и разума и контроле над производима нашег рада зависи да ли ћемо живети даље и у каквом свету. А последице по наше здравље увек долазе са задршком, али сигурно долазе! Питање како даље? - постаје императив данашњице.

“Расел примећује да развој науке и технике од људи захтева све више мудрости. Међутим, иако је наше време у погледу знања превазишло сва претходна, оно још увек није постигло већу мудрост, стога треба рећи пуним гласом - неопходна нам је нова перспектива”. (Ђукановић, 1996: 41)

Глобална еколошка криза у којој се човечанство налази, захтева сагледавање из више углова, а не само научних. С обзиром да наука не успева да спречи све чешће еколошке катастрофе у свету да смањи ризик од претеће еколошке катастрофе можемо констатовати да је крајње време за преображај културе, науке, човечанства, али и за другачији приступ еколошким питањима, у коме ће наука тражити помоћ и од других облика духовности пре свега религије.

\section{ЕКОЛОШКА СВЕСТ И (ИЛИ) ЕКОЛОШКА ДУХОВНОСТ}

Однос човека према природи део је филозофије, науке, религије, морала, обичаја и свакодневног живота. Наука сматра да у процесу развоја цивилизације, промене у средини су биле неминовне, па је тако као нужност настала и деградација. Паралелно са деградацијом, кроз историју се чине напори за бољу животну средину. Тај однос се најдиректније исказује у концепту еколошке свести. Еколошка свест је историјска категорија. Она настаје и мења се током историјског развоја друштва и прилагођава се друштвеним потребама, у зависности од карактеристика друштва и доминантних друштвених односа. Еколошка свест се формира не само под утицајем еколошких проблема, деградације природне средине која има обележје еколошке кризе, ни под утицајем научног сазнања и могућности њеног решавања, већ и под утицајем социјалних снага и промена система вредности. „Еколошка свест је настала у тежњи да се нађе решење за еколошку кризу, као кризу постојеће цивилизације, како би се очувала природа као оквир живота и колевка људске цивилизације“ (Марковић, 1994:10). Друштво има потребу стварања вредносног система својих чланова који одговара циљевима и потребама дате заједнице. У томе је посебно важан однос према вредностима животне средине.

Развој еколошке свести, зависи како од степена развоја друштва, тако и од промена у вредносним системима појединих земаља. „Еколошка свест је у директној вези са васпитањем и образовањем, што истовремено подразумева и добру обавештеност, и са моралним, односно етичким принципима који се у свим доменима живота примењују, у датим околностима и на одређеном простору“ (Ђукановић, 2001:176). Постоји много дефиниција еколошке свести, које указују 
на њену сложену природу. Како указује Цифрић (1989), различита појмовна одређења еколошке свести су резултат разноврсних теоријских приступа у њеном дефинисању, различитих система друштвених вредности и различитих друштвено-економских односа у оквиру којих се приступа одређивању појма. Различитим дефиницијама ипак је заједничко указивање на више димензија еколошке свести. Један од првих утемељивача социјалне екологије код нас Данило Ж. Марковић, који се активно бавио овим феноменом, истиче постојање бар шест аспеката или димензија еколошке свести (Марковић, 1994). То су: теоријска димензија (научно мишљење о односу човека и природе, вредносна (циљеви), социјална (идеја нове заједнице), историјска (могућности), политичка (ако је укључено деловање социјалних снага) и субјективна (личне претпоставке, уверења и жеље).

Минималистичка дефиниција еколошке свести укључује бар три њена саставна елемента сматра исти аутор. То су еколошко знање, вредновање еколошке ситуације и еколошко понашање. Еколошка свест подразумева активан ангажман човека у решавању еколошке кризе, а не само регистровање стања човекове средине у свести људи. Осим еколошког понашања еколошка свест садржи још два значајна елемента - еколошко знање и вредновање еколошке ситуације (Марковић, 1994:178). Еколошка свест је свест о околини која обухвата сазнања о еколошкој ситуацији, вредносно одређење, односно мотиве деловања, жеље и очекивања које се односе на човекову природну околину и понашање којим треба да се оствари еколошко стање коме се тежи. Еколошко знање је основа за еколошки начин мишљења, који људима омогућује да се другачије односе према природи. Однос појединца према еколошким вредностима у крајњем зависи од тога колико му оне припадају, односно у којој мери се он може идентификовати са њима и за њих везати своју егзистенцију и начин живота. Еколошке вредности су повезане са знањем. Као трећи елемент еколошке свести издваја се еколошко понашање појединца или групе у циљу решавања еколошких проблема које је у складу са еколошким знањима и вредностима. Испољавање позитивног еколошког понашања одређено је и индивидуалним особинама, потребама и могућностима. Овде би посебно желели да истакнемо да се темељ исправног еколошког понашања пре свега формира у раном детињству и у породици. У том смислу дете може да има исправно еколошко понашање а да нема развијену еколошку свет и еколошке вредности, као што одрастао човек може да има развијано еколошко занање а да нема право еколошко понашање.

Треба напоменути да еколошка свест није нека статичка, заувек дата категорија, већ врло динамична категорија. Мењање еколошке свести условљено је друштвеним околностима, па се са њиховим променама мењају и значења и понашања људи. Ако је свест наше знање о свету, онда је еколошка свест наше знање о еколошким проблемима, њихово одражавање у човековој глави. „Еколошка свест, у свом интегралном значењу, као целовит однос према природи, одликује се јасном опредељеношћу за чисту и здраву средину човековог живо- 
та и рада као значајну вредност сваког друштва. Дакле, то је свест о здравој човековој средини, свест о нужности, друштвеној оправданости постојања квалитета те средине. Таква свест не усваја никакво решење у развоју друштва које би било на уштрб човекове средине“ (Продановић, 1995: 100). Едгард Морен запажа и указује да је „еколошка свест свест о зависности наше независности“ односно да она мора да схвати да је околина, екостистем саморганизована, спонтана целина, и у том смислу децидано каже: „Еколошко образовање и васпитање треба да садржи критику уздизања победе човека над природом, односно става да је унакажавање природе најузвишенија епопеја и подвиг. Побеђена природа значи самоуништење човека“ (Морен, 1979: 233).

У свом развоју, како наводи Весна Милтојевић“ (2005:107-109),

„... еколошка свест прошла је кроз три фазе. У првој, се јавља свест о угроженој стабилности појединих екосистема и назива се енвиронментализам, чија је суштина покушај проналажења начина за заштиту појединих елемената животне средине. Првенствено се мисли на неке животињске врсте и очување неких територијалних целина. У другој фази јавља се свест о еколошкој угрожености на планетарном нивоу. Ова фаза је позната под именом „дубока екологија” (deep ecology), и указује на значај правилног схватања места и улоге човека у систему друштво - природа. Главна карактеристика ове фазе јесте да се залаже за поштовање живота уопште, па самим тим и живота човека као једне од врста на Планети. За трећу фазу је карактеристично схватање да је превазилажење еколошке кризе могуће само уз промену вредносног система, поштовање екохуманистичких вредности и промену индивидуалног и групног понашања на локалном и глобалном нивоу“.

Свака од ових фаза има своје специфичности, али и полази од заједничке премисе да је свест о угрожености животне средине од пресудног значаја за покретање акција за њену заштиту.

Мајка Природа је широкогруда и великодушно нуди своје дарове без икаквог ограничења, ослањајући се само на нашу свест да ћемо њене благодати што рационалније користити. Али иако човек важи за једино свесно биће на планети, ипак се најнерационалније понаша. Жудња за стицањем богатства, похлепа, технолошки напредак, мењање природних токова и законитости учинили су да човек уместо у хармонији са природом постане њен непријатељ. Данашња , циивилизација егоцентричности “ изазива кризу у више нивоа. антрополошком, социјалном, економском, политичком, културолошком и еколошком... То је управо основни разлог за Јована Зизјуласа (1994: 39), са којим се слажемо, да каже: „савремена цивилизација „незаустављивог напретка“ је генератор глобалне еколошке кризе, која у својој унутрашњости носи начело антропоцентричне или антропомонистичке кризе". За разлику од других живих бића, човек може живети 
посвуда на земљи, али не налази посвуда околину прикладну за себе. Да би очувао и развијао сам себе, човек мора околину трансформирати, мора је претворити у своје пребивалиште, због чега човек врши инревернције у природи. Наравно, у тим интервенцијама пресудно је питање мере човекових захвата у околину. Мера се одређује тако да се поштује сврха појединих делова природе под видиком целине. Поштујући сврху сваког елемента природе поштује се првобитни склад и равнотежа и не нарушава се (барем не превише) целина екосистема. Таквим захватима човек оплемењује своју околину и самог себе. То се, међутим, не догађа увек тако, при чему се узрок не именује његовим правим именом: унутрашња, духовна околина. Човек је унео несклад и неред у самог себе. Сликовито речено, нашао се усред трња и корова у себи - у својој савести, а онда и око себе - у својој околини. Загађеност унутрашње околине - савести, неизбеживо се одражава не само у човековом односу према Богу него и према другим људима, и према свим стварима. Након загађења унутрашње, моралне околине, човек почиње тровати и спољашњу околину, спољни свет, и почиње да се понаша као неограничени владар и корисник, а заправо бескрупулозни израбљивач природе.

Није само природа та која има свој ред, своје животно обличје које морамо поштовати, ако желимо живети у њој и од ње, него и човек у својој унутрашњости има свој ред. Да би могао живети у складу и мери са природом, он мора научити себе признати створењем и схватити да у себи мора имати унутрашњу чистоћу - екологију душе. Ако се не схвати та бит екологије, све ће се друго погоршати. Сведоци смо “развоја", који је у претходном веку оставио дубоке трагове, односно ожиљке, на телу Земље и Природе. То је аларм за наш разумни део да схвати куда идемо и да заустави посртање ка провалији. Оно што желимо да истакнемо, а што је и наша полазна основа у решењу еколошког промлема јесте да, по својој суштини, еколошки проблеми носе антрополошки карактер, будући да их је створио човек а не природа. Због тога се одговори на многа питања, која поставља криза околне средине, налазе у човечијој души, а не у сферама економије, биологије, технологије или политике. Природа се у истини преображава или пропада не само по себи него под утицајем човека. Узајамна веза антропологије и природе се крајње јасно открива управо у наше време, када свет истовремено преживљава две кризе: духовну и еколошку. У савременом друштву, човек понекад губи свест о животу као дару Божијем а понекад и сам смисао свог живота, који се повремено своди на физичко постојање. Човечанству које је заслепњено грехом не помажу ни колосалне техничке могућности: уколико је равнодушно према смислу, тајни и чуду живота оно не може да донесе истинску корист и често наноси штету. Незамисливо је да у условима духовне кризе дође до потпуног превазилажења еколошке кризе. Антропогена основа еколошких проблема показује да ми околни свет мењамо у складу са својим унутрашњим светом и да због тога преображај природе треба да почне од преображаја душе. Препородни Максим Исповедник, исправно примећује и поручује, ,човек ће бити у стању да чи- 
таву земњу претвори у рај тек онда када рај буде носио у самоме себи“ (2007, 131). Управо, зато рационалност не сме бити сама себи сврха, јер човек није и несме бити „мера свих ствари”, већ само средство очовечења човека. Стога, је неопходно да се у име истинске људске еманципације и ослобођења одлучно захтева отклањање штетних последица апсолутизирања рационалности. То заправо значи да би поред ума, требало на наозбиљнији начин узети у обзир људска хтења и осећања, веру, машту и суд: дакле, изнова обухватити и обновити све димензије људскости. Управо због тога, неопходан је сусрет, пре свега, науке и религије и проналажење заједничког пута у решавању глобалне еколошке кризе.

За правилан однос човека према природи и формирања праве еколошке свести посебно су важна две библијске поруке. Прва говори о човековој власти и послању да управља, господари овим светом: И благослови их Бог и рече им: Плодите се и множите, и напуните земљу, и себи је подложите! Владајте рибама у мору и птищама у зраку и свим живим створовима што пузе по земљи (Пост 1:28). Друга, говори изричито о човековој обавези према свету: Јахве, Бог, узме човека и постави га у еденски врт, да га обрађује и чува (Пост 2:15). Ова два текста шаљу нам јасну поруку да је човек истовремено и господар али и слуга света. Овакав поглед на свет и човека несумљиво је антропоцентричан, јер је усмерен према човеку као врхунцу Божијег стварања. Човек је круна свега створенога. Међутим, тај антропоцентризам није апсолутан него релативан: уз част да влада светом човек има обавезу да еденски врт, тј. врт свог постојања, своју околину, обрађује и чува. Према томе, антропоцентричност не значи неумереност, него тражи одређивање мере за коришћење и чување околине. Тамо где човек не мари за меру природе његово је деловање не само неприродно и протуприродно, него такође нељудско и протуљудско. Цело човечанство сноси одговорност за стање природе - Божије творевине. Реч Божија учи да је свет око нас дом, који је Господ створио и у којем је настанио човека (1Мојс, 1:28). Због тога је човек домаћин створеног света и није позван да се клања природи, већ само Твориу (Пм, 1:25). Добар однос човека према природи, испуњен свештеним страхом, заснива се на дубокој свести о томе да је Бог-cвет и све живо у юему, створио као добро (1Мојс, 1:8-25). Заједно са Светим Пророком Давидом сваки човек може да ускликне: "Јер си ме узвеселио, Господе, ... и у делима руку Твојих обрадоваћу се“ (Пц, 91:5). Дакле, можемо закључити да у светлости Светог Писма еколошка делатност се схвата као од Господа заповеђено благоугодно опхођење човека према тварном свету.

Религијска духовност нам шаље јасну поруку да су у односу човека према природи најважније две ствари: питање мере и љубав. Кроз бројна стољећа човекове немоћи пред силином природних појава, библијско човеково послање да господари земљом уопше није угрожавало околину, нити је представљало морални проблем. Више је био угрожен човек од околине (природних непогода) неголи околина од човека. У новије време проблем је настао не из обести, већ из чо- 
векове потребе да се животно снађе у том свету. Биљни и животињски свет условљен је и развија се и живи на сасвим одређеним деловима земље, у сасвим одређеним климатским и просторним условима живота. За разлику од других живих бића, човек може живети свуда на земљи, али не налази свуда средину прикладну за себе. Тек прилагођавањем околине, свет може постати човековим боравиштем. Да би опстао и развијао се, човек мора околину изменити, мора је претворити у своје пребивалиште. Дакле, човек мора мењати свет. Наравно, као кључно питање у мењању света поставља се питање мере човекових захвата у околину. Јасно је да је спољашња загађеност околине што је доживљавамо - огледало и плод унутрашње загађености којој не поклањамо довољно пажње. То су уједно недостаци покрета за заштиту природе. Они се с разумљивом и оправданом страшћу боре против загађења природе, а духовно самозагађење човека и надаље се сматра једним од његових права, његовом слободом. Тако дуго док подржавамо карикатуру слободе, наиме - слободе унутарњег разарања душе, њено ће спољашње деловање остати непромењено.

\section{НАРОДНА МУДРОСТ И ЕКОЛОШКЕ НАУКЕ}

Екологија је као наука утемељена у 19 веку. Међутим, као што смо и раније истакли људи давно схватили значај правилног односа према природи и њено очување. И пре него што су ималаи нека развијана еколошка знања, као дубоко религиозни људи, добро су разумели и и делатно спроводили те поруке. И наш народ као древни мудар народ, али и дубоко религиозан, давно је то схватио и изразио кроз низ народних мудрости. Наши преци у минулим временима, наравно да се нису сусретали са таквим еколошким проблемима као ми данас. Ти проблеми у тој мери тада нису ни постојали, а имајући у виду тадашњи ниво и темпо технолошког развоја - тешко да је ико могао и да их предвиди. За појам „екологије“ и „еколошке свести“ свакако нису чули. Међутим, то никако не значи да еколошка свест није била присутна у њиховој свакодневици. Посматрајући природу и друштво, њихова испољавања, законитости, односе и промене, наши преци су луцидношћу добрих посматрача и фином осетљивошћу за стварност, у мало речи знали да ухвате суштину односа човека према себи и другима (Ко свашто за зло прима, онај међу људе нек не иде!), природном и створеном окружењу, према животу у његовој укупности. То опажање и то разумевање представљају суштину еколошке свести, схваћене шире од граница које постављају појмови као што су: „природно окружење“, „животна средина“, „биосфера“, „екосфера“" и сл. што довољно говори о еколошкој свести наших предака. Те нас изреке истовремено подсећају да је домаћинско понашање које је у прошлости било део традиционалног односа овог народа према окружењу - поука и путоказ и за нас, данашње. Универзалним мислима време не одузима актуелност и вредност - већ додаје нове слојеве значења: У књизи Мисли неба и земље - зенац народне мудрости, коју је 
приредио Томислав Трбојевић, ${ }^{2}$ наилазимо на низ нарадних мудрости које нам дају јасну слику о томе како су се наши преци односили према природи и у којиј мери су имали развијану еколошку свест. Ево неких од тих “зденаца народне мудрости” која се тиче питања које ми обрађујемо:

Ко има поља има дио Бога; Ко не чува туђе, неће имати ни своје; Ни риба без воде ни звијер без горе; Рђава је тица која у своје гнијездо тори; У мемли и злато зарђа; Свак испред своје куће нека мете. (Језиком данашњих еко-активиста: Мисли глобално - делуј локално); Према Ђубрету и метла; Сам под собом дрво подсјеца"” (што управо ради човек данашњице); Доцкан је онда штеђети кад нестане; Зрно до зрна погача; Камен до камена палача; И храну ми штеди и ђецу ми храни; Ко купује што не треба, продаваће и оно што му треба; (Сврха живљења данашњег човека управо је постала потрошња, што нас води ка све већем задуживању) Комад је у туђој руци свагда већи; Коме није у ораху, није ни у товару (доста); Ко много дијели, скоро ће просити; Ко много иште мало му се дава (Скомност је код Срба увек била цењена врлина); Ко не зна на ораху, не зна ни на товару (захвалити); Ко не купи мрвице, неће стећи пунице; Ко тражи преко хљеба погаче, жели и овсенице; Ко у један пут много иште, с празном се торбом кући враћа; Крпеж и трпеж по свијета држе; Крпеж је сиротињска мајка; Крпеж кућу држи; Крпеж кућу тече; Крпи рупу док је маға (Проблем се решава, рупа запушава и крпи док је мала, кад постане велика тешко је закрпити је); Много добија онај који свашта не куnује; Не пружај се даље од губера (Знали су наши стари да се треба чувати мутних снова и превеликих жеља); Под једним пазухом не могу се двије лубенице носити; Преко мијере никаква добра није (никаква ствар, ништа) (Принцип праве мере, златне средине је оно што је увек било најбоље); Преко погаче хьеба тражити; У радише свега бише - у штедише јоште више (Рад је извор богатства али штедња чува и увећава богатство); Штедюа је прво течење; Што је марљивост стекла брижљивост нека чува; Што чоек не потроши, оно је добио (Твоје је само оно што сачуваш и оставиш својим потомцима); Чувај ме чувам те; Ако је мало млијека, а оно је близу ријека.; Ако не мирише, а оно барем и не смрди; Да нема вјетра, пауции би небо премрежсил (У природи је све по мери и све има своју сврху); Ђе није мачке ту и миши коло воде; Зна се злато и у ђубрету (Праве вредности увек остају праве); Једи зеље из свога врта; Ко има поља има дио Бога; Ко не храни мачку, храни мише; Ко не чува туђе, неће имати ни cвоје (Прави домаћински дух који су наши стари ценили и поштовали); Куд гођ суние тече - свуд се хљебаи пече; На живот и на здравље; Не би му ни ораха из руку узео. (Тако је неопран и гадан.); Не гули коре, не чини горе; Неће воћка испод дебла; Ни риба без воде ни звијер без горе; Ни све горе посјещи, ни без дрва дома дођи; Од невјешта и

\footnotetext{
${ }_{2}^{2}$ У књизи коју је је приредио Трбојевић налазе се наредне мудрости које је аутор нашао у делима Вука Караџића (Српске народне пословище), Васка Попе (Од злата јабука), Милана Кнежевића (Преља на месеиу) и часописа за књижевност и културу Расковник.
} 
гора плаче; Од невјешта и гора страда; Пошаљи луда у гору да побере сву гору (Грамзимљив људима, а то је данас постала карактеристика модерног човека никад доста); По пустој иркви и пси лају (Ово је упзорење које су наши наслутили и које нам се дешава, погледајмо наша опстошена села); Пусто млијеко и пси лочу; Риба без воде и вук без горе не може живљети; Свак испред своје куће нека мете; Страх чува винограде; Тешко коюу без поља а морнару без мора!; У град кад хоћеш, а из града кад те пусте; Фришак као кремен; Фришак као ра; Чак и над метларем има метлар; Чиста шеница као да је голуб (зрно по зрно) бирао; Чува га као мало воде на длану. (Држи га као мало воде на длану.); Чува га као очи у глави;Чувај ме, чувам те; Чувај се од угља потајна; Чувај ти мене од свога, а од туђега ћу се ја сам (чувати); Шта је највише, онога ће бити најмање, а шта је најмање онога ће бити највише; Што ми је с свијетом, то ми је с ивијетом; Шума ти мати.

Свака од ових порука може да се детаљно анализира и да се за сваку понаособ напише читав рад. Свакако да то сада није наш приоритет али овом приликом посебно указујемо на две поруке и о њима чинимо кратак осврт. Свак испред своје куће нека мете. Најважнија крилатица еколошких покрета у свету данас је: Мисли глобално а делуј локално. Дакле, еколошка криза има глобални карактер али њено решење треба да крено од тога да свако свако од нас испред своје куће нека мете. Дакле, јасно можемо видети мудрост наших предака и њихову далековидост. Друга: Ни све горе посјеци, ни без дрва дома дођи. Овде се јасно може видети како су наши преци схватили и истакли принцип мере, као најважнији (уз љубав) човеков осећај и принцип за однос са природом. Прирада нам даје, али морамо је и чувати. Еколошка свест, баш као и древна мудрост ма из ког времена и простора долазили не познају границе. Српске народне пословице то потврђују својом свежином, актуелношћу, присутношћу у овом времену, као и бројним мудростима из Јеванђеља (Бисер не ваља пред свиње баца$m u . .$.$) . Из тих зденаца мудрости можемо, ако смо и сами мудри, препо-$ знати смернице за човекво место у и улогу усвету (Нuита није ново на свету; Ко за светом плаче, без очију остаје.), непостојаности и пролазности живота (И то ће проћи; Свако чудо за три дана доста), судбини (И ја могу, и коњ ми може, али Бог не да!), Божанској свеприсутности (Бог не спава; Испод Бога нема се куђ!), вечности (Нећемо се оковати на овоме свету.), и наравно у изрекама које задиру иза привидне различитости и подељености појавног света у област јединства супротности и у којима можемо наћи принцип праве мере за којој су наши преци тежили: Ђе нема маленог, нема ни големог. Из једног дрвета икона и лопата бива. У ирној земљи бијело жито роди. У мало може бити доста а у доста мало.

\section{КА ЗАКљУЧКУ}

Древни народи, у које свакако спадају и Срби, у наталоженом народном искуству, знали су да препознају и искристалишу праве 
вредности. Мудрост долази са истог изворишта, из једног дрвета, дрвета живота, са својим коренима који сежу дубоко у прошлост. Богатсво народа огледа се и у његовј способности да разуме стварност и да је изрази у појмовима који врло прецизно означавају народну мудрост сажету у једној реченици (коју данас најчешће називамо афоризмом). Дакле, народна умотворина је творевина ума, али и доказ мудрости и старости једног народа. Традиционална мудрост сачувана у српским народним пословицама још једном нас подсећа да укупан однос човека према животу и универзалним темама - представља темељ еколошке свести која је неодвојива од универзалне свести. А та народна, а универзална свет нам јасно поручују: Како посијеш, онако ћеш $u$ пожнети.

Домаћински људи, који су увек били и дубоко религиозни, према природи се опходе љубавно, благо, нежно, не непријатељски, не сурово и сирово. Која је основна порука коју су нам наши стари оставили. "Светосавска култура и екологија нас уче да се најпре спасимо од самих себе. Спасимо се од робовања идејама, иметака (материјалних и духовних), од свих могућих застрањења, страпутница, лутања, сурвавања у урвине. Схватимо себе, доживимо себе, као део, ни већи ни мањи, ни значајнији ни мање значајнији, једног свеколиког организма, Свеорганизма, део који је најсвеснији, самим тим и најодговонији, најпожртвованији део ове заједнице. То није само етички, већ и есенцијални принцип постојања и опстанка човека, а самим тим и целе планете” (Анђелковић, 2007: 165). Према томе полазна основа православне духовности, у објашњењу односа човека, природе и твари, јесте:

\begin{abstract}
“Кроз грех је зло ушло у човека, а кроз човека у природу и све твари. Нема зла мимо греха. Харматологија човека у себи садржи и харматологију твари, односно, историја прве истовремено је и историја друге. Стога је, харматичан (греховни) карактер природе и твари чисто антропоморфичан. Дакле, однос човека и природе је такав да се налазе и крећу један према другом управој сразмери. Метафизичка мистика личности објективира се, материјализира се у свету твари. Животом човечје личности детерминисан је живот природе. Из анализе хамартологије човека и природе резултира закључак, да проблем реинтеграције природе, лежи у решењу проблема дехаматризације (обезгреховљења) човекове личности. Решење проблема, јесте у уклањању узрока дезинтеграције човека одстрањивањем греха из његове личности. Порука је, дакле, јасна: Екологији природе најпре мора да предходи екологија душе". (Анђелковић, 2007:165-166)
\end{abstract}

У том смислу, савремена постхришћанска цивилизација, “цивилизација егоцентризма”, „цивилизација лажне и погрешне антропологије, носи у себи семе и начело сопственога уништења и пропасти, али и уништења и пропасти целог света. Она у свом „незадрживом” технолошко-економском напредовању не може а да не изазива сваку 
врсту кризе-антрополошке, социјалне, економске, политичке, културолошке и еколошке. Развијајући се технолошки и економски, она разара саму себе и свој свет, своје природно окружење, животну средину, планетарни Икос" (Пурић, 2013: 96). Савремена цивилизација "незаустављивог напретка“" је уствари, главни генератор глобалне еколошке кризе, јер је њено унутрашње начело, начело антропоцентричне, тачније, антропомонистичке кризе. У приступу еколошком проблему хришћанска духовност полази од важне чињенице: најпре, да се савремена постхришћанска цивилизација бави последицама еколошке кризе без удубљивање у њене дубинске духовне и антрополошке, тј. егзистенцијалне узроке; и потом, да је немогуће, полазећи од скривених духовних начела на којима је утемељена савремена цивилизација, а која нужно производе еколошку кризу, ни уз примену свих најсавременијих научних и технолошких напора, метода и средстава, превладати ту кризу, јер се сваки такав покушај врти унутар “зачараног круга“: погрешна антропологија проузрокује еколошку кризу, коју човек ,генератор те кризе, покушава да реши путем погрешне екологије.

Ако се показао, а јесте, да актуелни еколошки приступ и образац (парадигма) не даје очекиване, а тако потребне резултате, онда је потреба за трагањем за новом парадигмом све актуелнија. Потребан нам је један други, другачији поглед на екологију ослобођен стега и доминације теорије и методологије којој је припадала класична екологија а која се искључиво базирала на научним претпоставкама. Дакле, потребна нам је рефлексивна екологија саморефлексивни приступ еколошким темама. У том смислу изузетно су значајни увиди Јована Пурића, који истиче три ствари који су битне као предуслов правилног поимања и делотворног бављења еколошким проблемом: са садашње ускогруде и кратковиде антропомонистичке етике човека као рационалистичког субјекта који третира сву твар као пуки објект своје рационалности на једну свеобухватну антропо-космичку етику која подразумева дубинску саодносност човека и космоса у протолошкој, историјској и есхатолошкој перспективи; са утилитаристичке етике хедонистичког индивидуализма који читав свет претвара у средство за задовољавање сопствених жеља на подвижничко-саможртвену етику живљења и делања ради свих и за све, уз потовање свих и свега као онога што има свој интринсични смисао и вечну вредност у Богу; са етике доминације над творевином на етику евештениковања у творевини, свештеничког возглављивања творевине кроз њено евхаристијско приношење Богу (Пурић, 2013: 101).

Сама екологија, говор и расправа о људској околини, треба да прерасту у екофилију, тј. у пријатељство и љубав према околини, у љубав из које се рађа нова еколошка култура холистичког, целовитог моралног погледа на свет. Дакле, оно што је је неопходно,услов свих услова, што морамо прво схватити и од чега морамо најпре кренути јестеда: ма које еколошке мере да предузимамо у циљу заштите природне средине, те мере и ти пројекти не могу и неће бити трајнога карактера све док не буду засновани на искреној љубави и прожети истинском љубавиљу према створеној материји-свету. Ако човек не открије ту првобитну љубав према свету и творевини, он ће бити осуђен на живот проти- 
ван својој природи. Љубав на подручју еколошке етике значи разумноосећајан однос према свету око нас, посебно према животу на свим његовим ступњевима: биљном, животињском и људском. Можемо уочити да данашњи свет постаје све мање хришћански ${ }^{3}$, све се више удаљава од Христа и у исто време све мање еколошки, претварајући природу искључиво у средство експлоатације ради задовољења људских потреба и хтења. Поремећена природа у човеку, као последица модерне културе, изазвала је неодговорно понашање у целокупном природном окружењу. Полазна основна којој се заснива овај рад, јесте став: будући да је еколошку кризу изазвао човек, а не сама природа, по својој суштини еколошки проблеми носе антрополошки карактер. Због тога би требало одговоре на многа питања потражити у човечјој души, а не само у сферама екологије, технологије, политике. Данас је узајамна веза антропологије и природе јача него икад управо због тога што свет истовремено преживљава две кризе: духовну и еколошку. Дакле из теолошког, посебно прававославног угла посматрања еколошки проблем јесте неправилно одношење човека према природи. У том смислу, еколошки проблем представља првенствено духовни проблем који се односи на духовну кризу човековог односа према природи.

Еколошка криза само је симптом који указују на то да смо у неравнотежи с Природом. Да бисмо решили еколошку кризу, требамо научити законе који делују у Природи и иста начела имплементирати у наше друштво. Другим речима, требамо спровести општи закон Природе, на људском нивоу. Природа је беспрекорна и делује у потпуном складу. Сви проблеми у свету произлазе из нашег несклада са законима Природе. Будући не схваћамо да смо саставни део Природе, склони смо мислити како егоистични ставови једних према другима нису повезани са проблемима попут еколошке кризе. У пракси, међутим, све што чинимо утиче на сваки ниво Природе, укључујући и екологију. Наше занемаривање околине иде уз бок са нашим међусобним занемаривањем. Према томе, не можемо уистину покушати исправити наш однос према околини занемаривајући односе међу нама самима. Ал Гореов искрени позив свету на буђење и суочавање са изазовима наше околине свакако је важан. Порука је јасна: излечење., али и спас рањене природе, погођене човековом небригом, себичношћу и деструктивношћу, једино је могуће најпре духовним препородом самог човека. Стога се чини сасвим умесним пророчки став које изговорио МерлоПонти: двадесет први век ће бити религиозан или га уопште неће бити.

\section{ЛИТЕРАТУРА}

Антонић, Слободан. „Дехристијанизација и српско друштво“. Коращии XLVIII, 7-9 (2014): 99-115.

\footnotetext{
${ }^{3}$ Слободан Антонић исправно користи термин дехристијанизација, који је бољи термин од секуларизације, и који нам указује да је реч о планском и систематском удаљавању људи од хришћанства, а не о спонтаном процесу потискивања религије из јавног живота на шта конотира секуларизација. Антонић Слободан, Дехристијанизација и српско друштво, Кораци XLVIII, свеска 7-9, Крагујевац: Народна библиотека „Вук Караџић“, 2014, 99-115.
} 
Анђелковић, Петар. Правосавље и српско друштво пред ововременим изазовима. Алексинац: Висока школа струковних студија за образовање васпитача. 2007.

Бек, Урлих. Ризично друштво: У потрази за изгубљеном сигурношћу. Нови Сад: Академска књига. 2011.

Бодријар, Жан. Симулакрум и симулаџија. Нови Сад: Светови, 1991.

Горц, Андре. Екологија и политика. Београд: Просвета, 1982.

Ђукановић Мара. Еколошки изазов. Београд: Елит, 1991.

Ђукановиђ. Мара. Животна средина и одрживи развој. Београд: ЕЛИТ, 2001.

Зизјулас Јован. „Очување Божје творевине“. Беседа 1-4 (1994): 13-42.

Марковић, Данило Ж. Соиијална екологија. Београд. Завод за уџбенике и наставна средства. 1994.

Марковић, Данило Ж. „Урбана екологија и еколошка свест“. У Урбана култура и екологија. Ниш: Градина. 2004.

Милтојевић, Весна. Еколошка култура. Ниш: Факултет заштите на раду, 2005.

Морен, Едгар. Дух времена, ІІ. Београд: БИГЗ. 1979.

Пурућ, Јован, Епископ. Еколошке теме. Ниш: Задужбина Светог Манастира Хиландара. 2013.

\section{THE WELL OF FOLK WISDOM AND ECOLOGICAL AWARENESS}

\section{Summary}

Today it is very modern and popular to talk about ecology. The specter of ecology (to use Marx's phrase, as he long ago spoke of communism) is circulating around the world. However, in that speech, we see a clear paradox in these efforts and in numerous institutes and organizations dealing with ecology. Never more have there been talk about ecology, never more nave there been ecological movements, never more have there been spending money to solve ecological problems, and it seems that humanity has never been closer to the apocalypse, mostly precisely for ecological reasons. Newly composed ecologists, whose mouths are full of stories about ecological awareness, but without practical foundation, sprout like mushrooms after rain. Rare are those who call themselves ecologists, and who have understood the true essence of the ecological problem, and even less those who see a real way out of the darkness of the ecological crisis in which humanity has fallen. What is the key reason for this? Where are the spells of that paradox. This paper intends to offer a different view of the causes of the ecological crisis and offer a different solution to the ecological problem.

Key words: folk wisdom, ecological crisis, ecological consciousness, ecology of spirit. 